研

究

\title{
$\mathrm{MA}$ 合成した Fe-48at\% Cr 合金の SPS 成形におよぼす Al 添加の効果
}

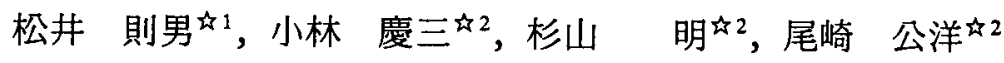 \\ 41名古屋市工業研究所, † 456-0058 名古屋市熱田区六番三丁目 4-41. \\ 的2名古屋工業技術研究所, 广 462-8510 名古屋市北区平手町 1-1.
}

\section{Effects of Al Addition on Forming of Mechanical Alloyed Fe-48at\%Cr Alloys by SPS Process}

\author{
Norio Matsui ${ }^{41}$, Keizo kobayashi ${ }^{\not 2}$, Akira Sugiyama ${ }^{42}$ and Kimihiro Ozaki ${ }^{2}$ \\ * INagoya Municipal Industrial Research Institute, 3-4-41 Rokuban Atsuta-ku, Nagoya 456-0058. \\ ${ }^{\not 2}$ National Industrial Research Institute of Nagoya, AIST, MITI, 1-1 Hirate-cho Kita-ku, Nagoya 462-8510.
}

Received July 27, 1998

\section{SYNOPSIS}

Fe-48at\% $\mathrm{Cr}$ alloy powders were synthesized by mechanical alloying (MA) of $\mathrm{Fe}$ powder and $\mathrm{Cr}$ powder using a planetary ball milling for $180 \mathrm{ks}$ under $1.33 \mathrm{kPa}$ argon gas atomosphere. In order to consolidate the MA powder at a lower temperature, $0.5 \sim 5.0$ mass\% Al powders were mixed with the MA powder for $36 \mathrm{ks}$ by a planetary ball mill. The results of DSC indicated that Al powders were not reacted with mechanical alloyed powders and remained as primary powders. The obtained mixed powders were consolidated by spark plasma sintering (SPS) apparatus.

By the addition of $\mathrm{Al}$, the starting temperature of the shrinkage of mixed powders during SPS was reduced to lower of $100 \sim 150 \mathrm{~K}$ than that of mechanical alloyed powders. However, the sintered bodies containing more than 2.5 mass\% $\mathrm{Al}$ were brittle because of the formation of $\mathrm{FeAl}$ intermetallic compound during a sintering process. The sintered body which contained 0.5 mass $\% \mathrm{Al}$ had fine microstructure and the hardness of $350 \sim 370 \mathrm{Hv}$.

\section{KEY WORDS}

mechanical alloying, spark plasma sintering, $\mathrm{Fe}-\mathrm{Cr}$ alloy, Al, $\mathrm{FeAl}$

\section{1 緒言}

$\mathrm{Fe}-\mathrm{Cr}$ 合金はフェライト系ステンレス鋼と総称され，耐応力 腐食割れ性 ${ }^{1)}$ や而孔食性 ${ }^{2)}$ に優れている. また, $\mathrm{Ni}$ を含有しな いので省資源の観点からも注目されている ${ }^{3,4}$. Fe-Cr合金に関 しては多数の報告)がなされているが，その製造方法のほとん ぞは溶解法である.溶解法では $\mathrm{Fe}-\mathrm{Cr} 2$ 元系状態図6にあるよう に，47〜49at\%Cr 組成において；硬くて脆い $\sigma$ 相の生成》が考 えられる.そこで, 著者らはこれまでにメカニカルアロイング (以下，MAと記す)法と放電プラズマ焼結 (以下，SPS と記す) 法を組み合わせた MA-SPS プロセスにより Fe-Cr 合金を作製 し，その合金化の過程を含めたMA粉末の特性および焼結体の 特性について報告してきた ${ }^{8,9}$. Fe-48at\%Cr合金を MA-SPS プロ セスで作製した場合，不純元素としてSiが約 2 mass\%以上混入 しなければ $\sigma$ 相が生成しにくいこと，SPSによる焼結では 1073Kで 300s 間保持することにより緻密な焼結体が得られる ことなどを明らかにした。

しかし，SPS成形においては黒鉛型を使用するため，焼結時 に型と $\mathrm{Fe} や \mathrm{Cr}$ との反応が愳念される．そのため，より低温で
の焼結が望ましいものと考えられる.これまでに高融点材料の 低温焼結方法として Al の液相を利用した金属間化合物の低温 焼結に関する報告 ${ }^{10,11)}$ がなされており，本合金についても $\mathrm{Al} の$ 利用による低温焼結の可能性が期待される.

そこで，本研究では MA 合成した $\mathrm{Fe}-48 \mathrm{at} \% \mathrm{Cr}$ 組成の粉末に $\mathrm{Al}$ 粉末を添加し，焼結性の変化について検討した.

\section{2 試料および実験方法}

$2.1 \mathrm{Fe}_{52} \mathrm{Cr}_{48}$ 合金の MA 合成

出発原料として Fe 粉末 $(99.86 \mathrm{mass} \% \mathrm{Fe}$ ) と Cr 粉末 $(99 \mathrm{mass} \% \mathrm{Cr}$ ) を用い $\mathrm{Fe}-48 \mathrm{at} \% \mathrm{Cr}$ 組成に秤量後，雲囲気制御が可能な遊星型 ボールミル $\left(\right.$ 伊藤製作所製 $\left.\mathrm{LA}-\mathrm{PO}_{1}\right)$ を使用して, 自転および公 転の回転数が 200 r.p.m. で $180 \mathrm{ks}$ 間 MA 処理を行った. 容器 $(500 \mathrm{ml})$ およびボール $(10 \mathrm{~mm} \phi)$ には硬質鋼 (11mass\%Cr) 製を用 い，ボール重量の $10 \%$ に相当する粉末を処理した.また，MA の雾囲気は $1.33 \mathrm{kPa}$ の減圧アルゴンガス雾囲気とした. 得られ た $\mathrm{Fe}-48 \mathrm{at} \% \mathrm{Cr}$ 組成の MA 粉末 (以下, $\mathrm{Fe}_{52} \mathrm{Cr}_{48}$ 粉末と記す) は $\mathrm{X}$ 線回折により相の同定を行った。 


\section{$2.2 \mathrm{Fe}_{52} \mathrm{Cr}_{48}$ 粉末 $+\mathrm{Al}$ 混合粉末の作製}

$\mathrm{Fe}_{52} \mathrm{Cr}_{48}$ 粉末は粒径が細かく硬度が高くなっており，A1粉末 (99.5mass\%Al，平均粒径 $100 \mu \mathrm{m}$ ) との比重差もあるため，通常 の混合機では均一な混合が難しかった。そこで,MAに使用し た遊星型ボールミルを混合機として使用した。Al粉末の添加 量は $\mathrm{Fe}_{52} \mathrm{Cr}_{48}$ 粉末の重量に対して $0.5,1.0,2.5$, 5.0mass\%と変化 させた. 容器およびボールの大きさや材質，混合した粉末の 重量比拉よび雲囲気は上記のMA処理と同様である.たたし， 混合中にAI粉末がMA粉末と反応しないように容器の回転数 は150r.p.m.に減速し，混合時間も36ks とした，得られた $\mathrm{Fe}_{52} \mathrm{Cr}_{48}$ 粉末 $+\mathrm{Al}$ 混合粉末 (以下, 混合粉末と記す) は X線回 折による相の同定, SEM/EDXおよび熱分析による解析を行っ た.

\section{3 混合粉末の固化成形}

固化成形は放電プラズマ焼結機(住友石炭鉱業製 SPS-510L) を使用し，33MPa の加圧下において 1073Kまで加熱して 300s 間保持することにより行なった. 成形は内径が $15 \mathrm{~mm} \phi$ の黒鉛 型を用い，温度測定は $\mathrm{K}$ 熱電対を黒鉛型内に $3 \mathrm{~mm}$ 挿入して 行った。このとき，焼結に伴う試料寸法(厚み)の变化を測定 した.なお，試料寸法の変化量には加熱に伴う黒鉛型の熱膨 張も含まれている．得られた焼結体はビッカース硬度測定， 光学顕微鏡による組織観察およびX線回折による相の同定を 行った.

\section{3 実験結果および考察}

3.1 混合粉末の特性

$\mathrm{Fe}_{52} \mathrm{C}_{48}$ 粉末の $\mathrm{X}$ 線回折パターンを Fig.1に示す. $\mathrm{Fe}$ と $\mathrm{Cr}$ が 均質化したと考えられる $\mathrm{Fe}-\mathrm{Cr}$ のピークだけが検出された.こ の $\mathrm{Fe}_{52} \mathrm{Cr}_{48}$ 粉末に 0.5 5.0mass\%の Al 粉末を添加し, 36ks 間混

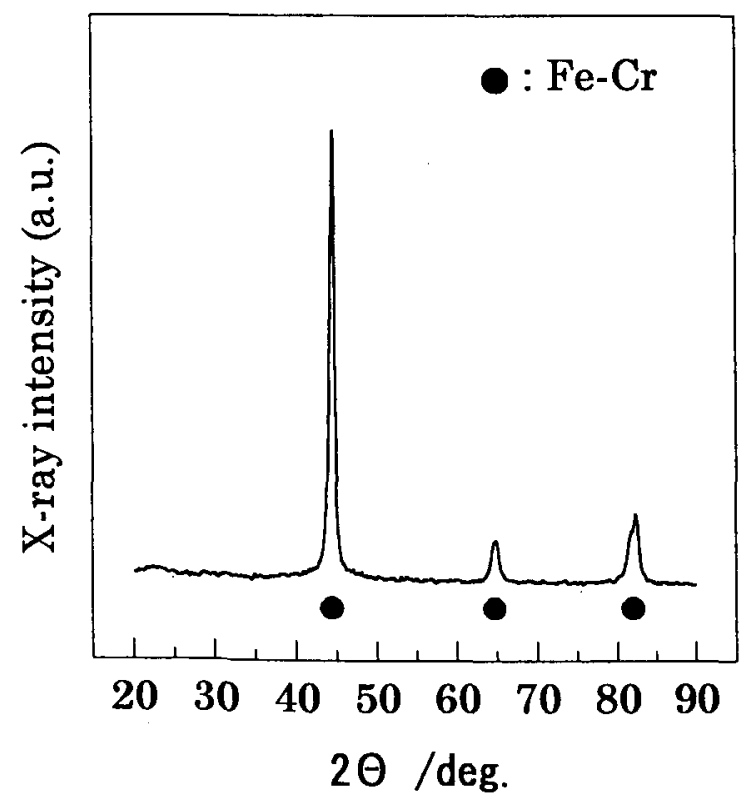

Fig.1 X-ray diffraction patterns of mechanical alloyed $\mathrm{Fe}_{52} \mathrm{Cr}_{48}$ powders milling for $180 \mathrm{ks}$.
合した粉末のX線回折パターンを Fig.2に示す.すべての混合 粉末は MA 粉末と同じ Fe-Crのピークを有しており， $\mathrm{Al}$ の明 瞭なピークは観察されなかった. 5.0mass\%Alを添加した混合 粉末からはAlのピークか微量ながら検出されたが, Al化合物 のピークは検出されていない．この混合粉末の SEM/EDXに よる分析結果をFig.3に示す. 軟らかいA1粉末が硬質な MA 粉 末を包み込んでいる様子がわかる，遊星型ボールミルを用い て回転数 150r.p.m.で 36ks 間行った混合では, Al粉末が MA粉 末と反応せず $\mathrm{Al}$ の状態で残っていることが確認できた.

5.0mass\%Al 混合粉末の熱的特性を DSCにて調べた結果を Fig.4に示す. 約 933Kで Al の溶融が生じ (Fig.4 の矢印 a), そ の直後に発熱反応(Fig.4の矢印b)か観察された。すなわち, Al が溶融すると同時に化合物を生成することが判った。このた め, $\mathrm{Fe}-\mathrm{Cr}$ 合金では Al の液相を利用して焼結性を改善するこ とは難しいことがわかる. そこで，Al が溶融する直前の軟化 状態を利用することにより，焼結性の促進を図った。なお， $850 \mathrm{~K}$ 付近で観察された発熱ピークは $\mathrm{Al}$ 粉末表面に圧着され た MA 粉末 (Fig.3 参照) が $\mathrm{Al}$ と部分的に反応したものと推定 される.

3.2 混合粉末の固化成形

SPSによる固化成形で，混合粉末を $1073 \mathrm{~K} て ゙ 300$ s 間保持し ても，Al粉末を添加した効果は観察されなかった.この原因 として SPS の昇温速度が $0.83 \mathrm{~K} / \mathrm{s}$ と速いため, $\mathrm{Al}$ が軟化状態 で十分な岕力を受けて変形することができないものと考えら れた. すなわち， $\mathrm{Al}$ の変形が十分生ずる前に，化合物が生成 する温度へ加熱されたものと推察される.このため, Al の融 点以下で一定時間保持する予備成形実験を行った。その結果， $723 K て ゙ 300 s$ 間保持した場合の密度が最も高くなることが判っ

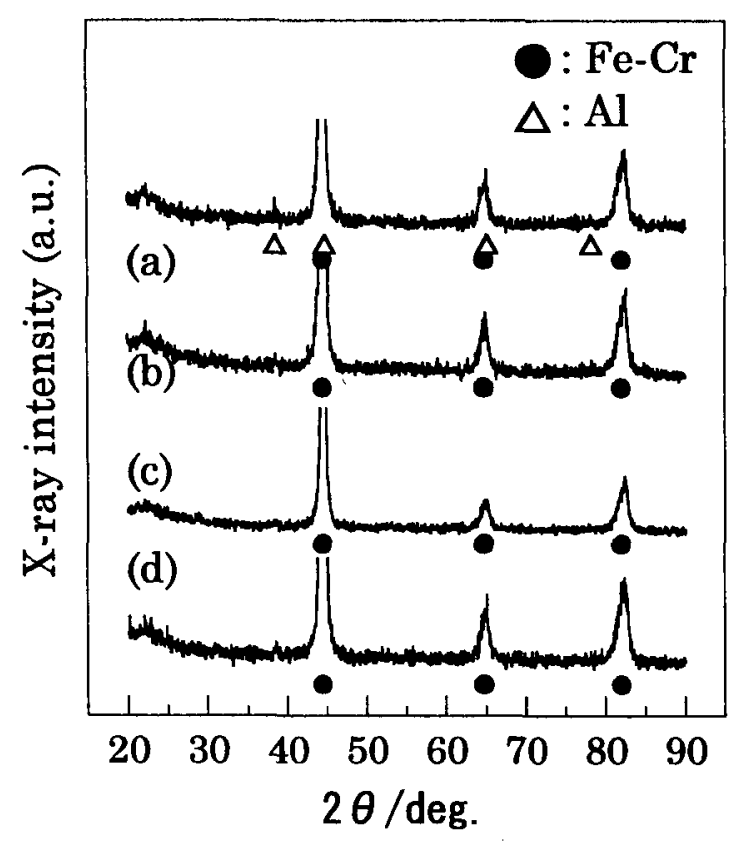

Fig.2 X-ray diffraction patterns of mechanical alloyed $\mathrm{Fe}_{52} \mathrm{Cr}_{48}+\mathrm{Al}$ powders mixing for $36 \mathrm{ks}$. (a) $5.0 \mathrm{mass} \% \mathrm{Al}$, (b) 2.5 mass $\% \mathrm{Al}$, (c) $1.0 \mathrm{mass} \% \mathrm{Al}$ and (d) $0.5 \mathrm{mass} \% \mathrm{Al}$ 

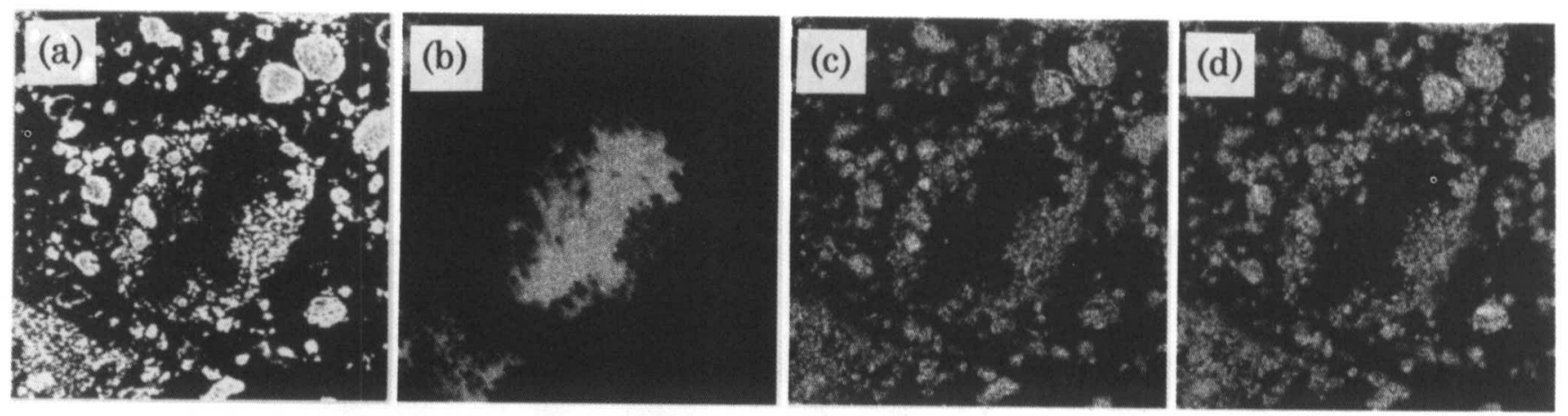

$50 \mu \mathrm{m}$

Fig.3 SEM image and EDX mappings of mechanical alloyed $\mathrm{Fe}_{52} \mathrm{Cr}_{48}+5.0$ mass $\% \mathrm{Al}$ powder. (a) SEM image, (b) $\mathrm{Al} \mathrm{K} \alpha$, (c) $\mathrm{Fe} \mathrm{K} \alpha$ and (d) $\mathrm{Cr}$ $\mathrm{K} \alpha$

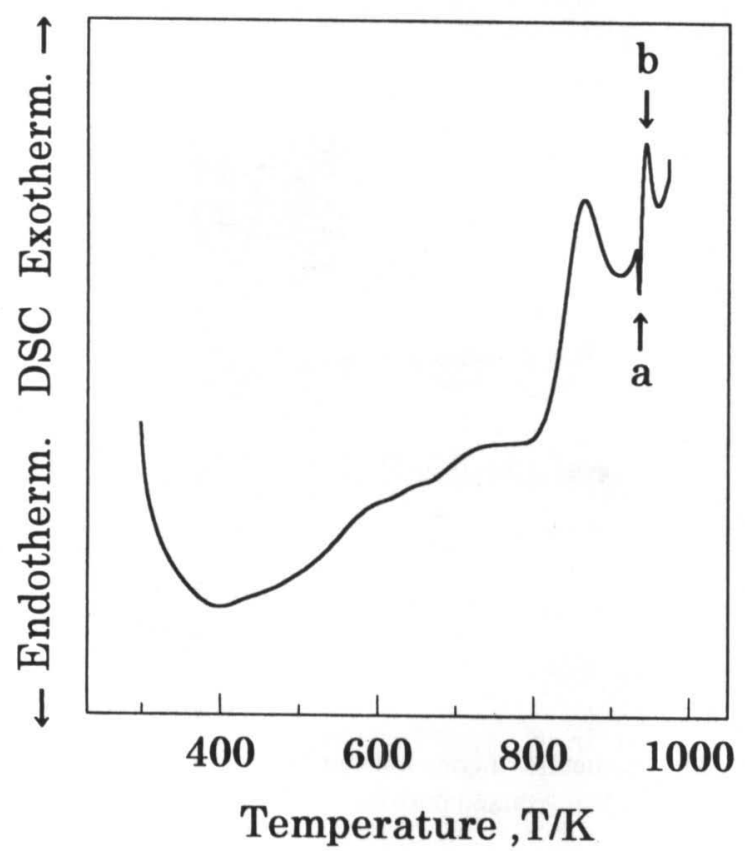

Fig.4 DSC curves of mechanical alloyed $\mathrm{Fe}_{52} \mathrm{Cr}_{48}+5.0$ mass\%Al powder.

た.そこで, SPSにおける焼結パターンは $723 \mathrm{~K} て ゙ 300 s$ 間保持 した後, $1073 \mathrm{~K}$ で $300 \mathrm{~s}$ 間保持する二段成形とした. $\mathrm{Fe}_{52} \mathrm{Cr}_{48}$ 粉 末および混合粉末の SPS 成形における収縮曲線を Fig.5 に示 す. $\mathrm{Al}$ 粉末を含まない MA 粉末は $723 \mathrm{~K} て ゙ 300 \mathrm{~s}$ 間保持しても ほとんど収縮しなかったが，混合粉末は保持中に収縮が進行 していることがわかる. また, 混合粉末は $1073 \mathrm{~K}$ まで加熱す る際にも急激な収縮を示している。これらの結果から， $\mathrm{Fe}_{52} \mathrm{Cr}_{48}$ 粉末に $\mathrm{Al}$ を添加すると収縮開始温度が低くなり, 黒鉛 型との反応も減少するものと考えられる。

得られた焼結体のX線回折パターンをFig.6に示す.すべて の焼結体から $\mathrm{Fe}-\mathrm{Cr}$ のピークが検出された.これは $\mathrm{Fe}_{52} \mathrm{Cr}_{48}$ 粉 末の SPS 成形体と同じ結果であった.しかし, $\mathrm{Al}$ 粉末の添加 量が 2.5 mass\% および 5.0 mass\% の焼結体からは, 微量ながら $\mathrm{FeAl}$ のピークが検出された. なお, FeAlのピーク高さは, $\mathrm{Al}$

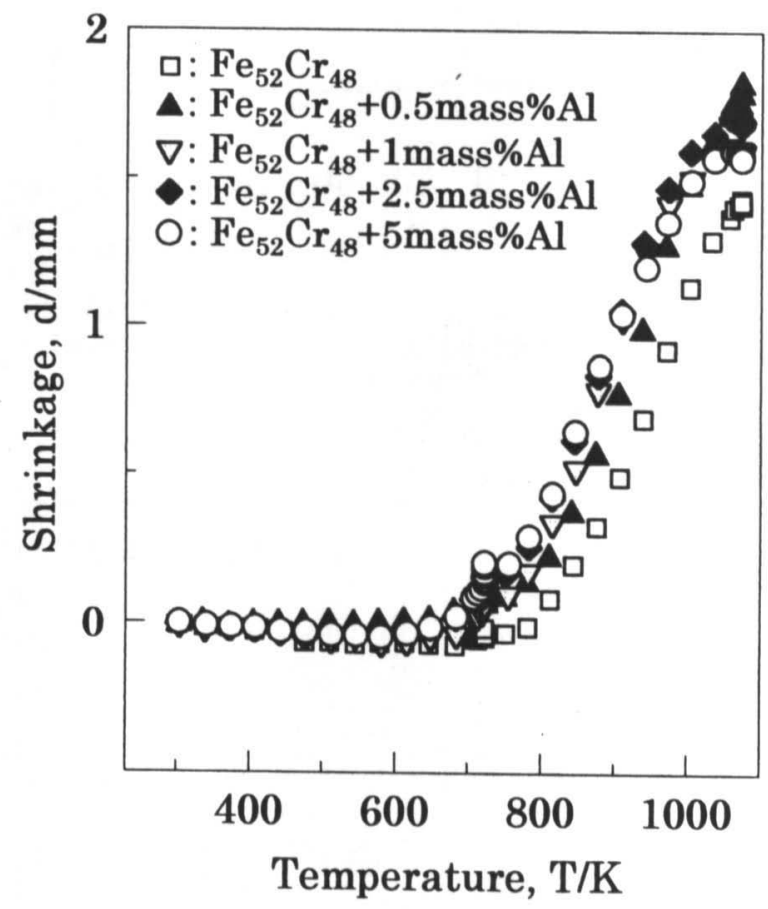

Fig.5 Shrinkages of mechanical alloyed $\mathrm{Fe}_{52} \mathrm{Cr}_{48}+\mathrm{Al}$ powders plotted against temperature during a SPS process.

粉末の添加量が多い5.0mass\%Al焼結体の方が大きくなってお り, $\mathrm{FeAl}$ が多く生成したものと推察される.この化合物は混 合粉末では観察されなかったことから, Fig.4のAlの溶解直後 に生ずる発熱反応によって, SPS 成形時に生成したものと考 えられる.

得られた焼結体のビッカース硬度をFig.7に示す. Al粉末の 添加量が 1.0mass\%以下では, Fe-48at\%Cr合金の硬度とほとん ど差がなく $350 \mathrm{Hv}$ 程度であった.しかし，2.5mass\%以上 $\mathrm{Al}$ を 添加した焼結体では $\mathrm{Al}$ 量の増加とともに硬度は上昇してい る. 5.0mass\%Al を添加した焼結体にビッカース硬度測定を行 うと, Fig.8に示すように圧痕の周囲にクラックが発生する場 合があった.クラックが発生した場合の硬度は $500 \mathrm{Hv}$ 前後で あることから, FeAl 化合物相が含まれる部分であろうと推察 


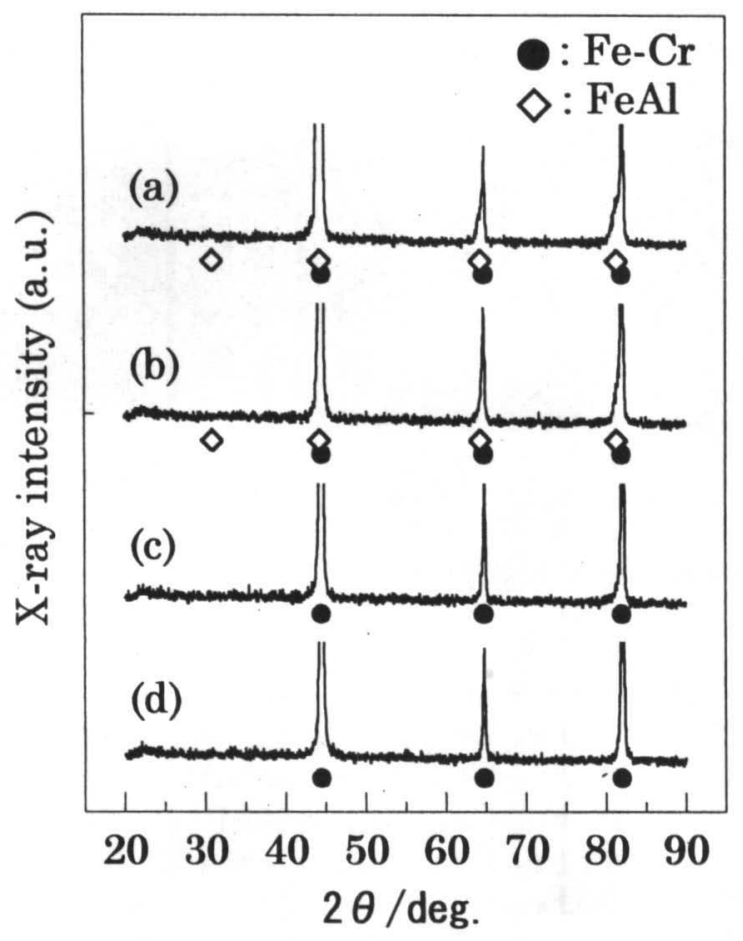

Fig.6 X-ray diffraction patterns of consolidated $\mathrm{Fe}_{52} \mathrm{Cr}_{48}+\mathrm{Al}$ alloys by SPS using mixed powders. (a) $5.0 \mathrm{mass} \% \mathrm{Al}$, (b) 2.5 mass $\% \mathrm{Al}$, (c) $1.0 \mathrm{mass} \% \mathrm{Al}$ and (d) 0.5 mass $\% \mathrm{Al}$

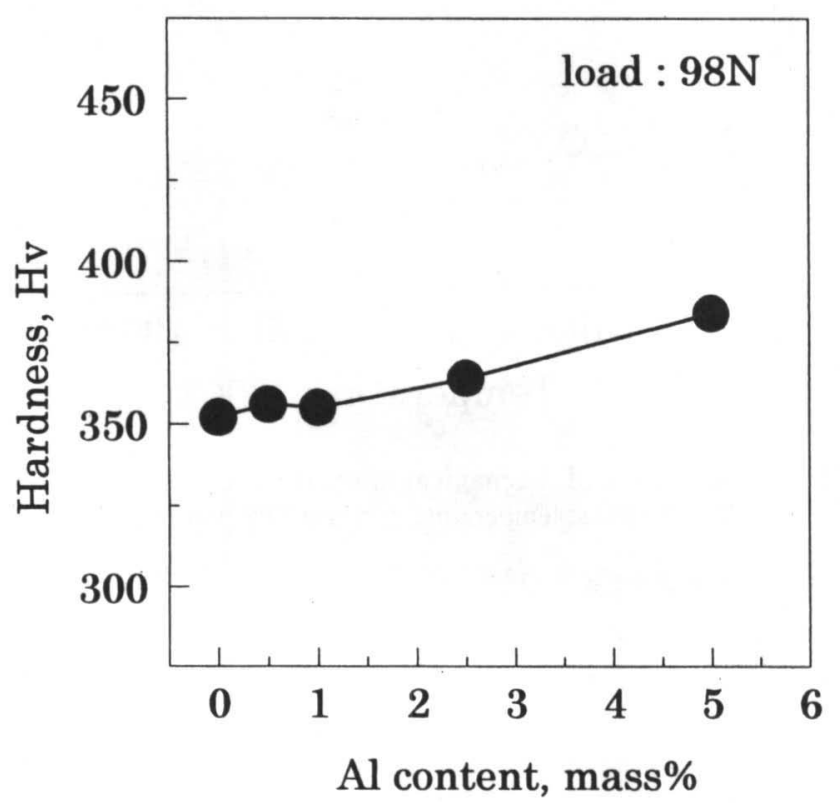

Fig.7 Hardness of consolidated $\mathrm{Fe}_{52} \mathrm{Cr}_{48}+\mathrm{Al}$ alloys at various $\mathrm{Al}$ contents by SPS using mixed powders.

される. Al 添加することにより $\mathrm{FeAl}$ 金属間化合物が生成す ると, 焼結体の機械的特性は低下するものと考えられる.

$0.5 \mathrm{mass} \% \mathrm{Al}$ を添加した焼結体の光学顕微鏡組織を Fig.9に 示す.ポアもほとんどなく, 均一微細な組織を示しており, そ の硬度は350〜370Hvであった. 本混合粉末はSPSを用いた固

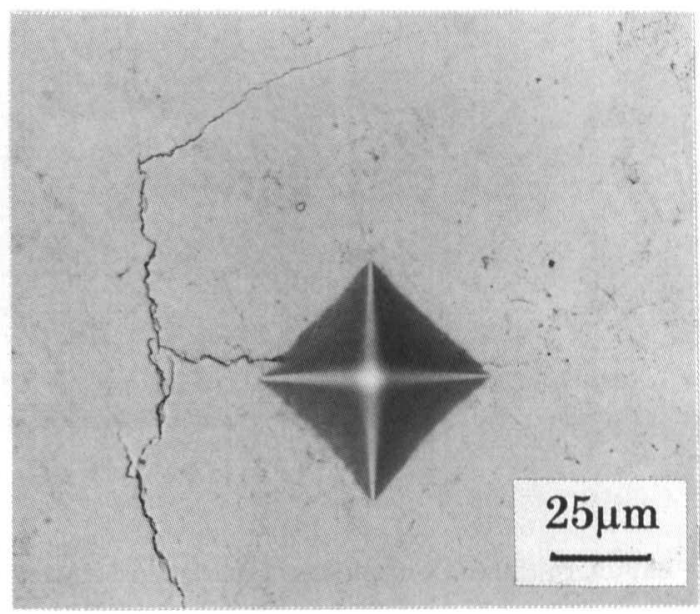

Fig.8 Optical micrograph around the indentation for vickers hardness of consolidated $\mathrm{Fe}_{52} \mathrm{Cr}_{48}+5$.0mass\% Al alloy by SPS using mixed powder.

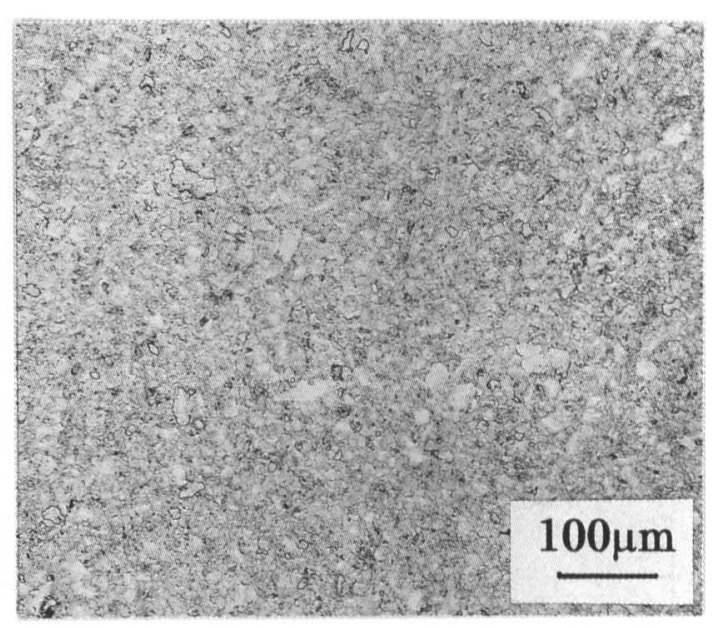

Fig.9 Microstructure of consolidated $\mathrm{Fe}_{52} \mathrm{Cr}_{48}+0.5$ mass\% $\mathrm{Al}$ alloy by SPS using mixed powder.

化成形において約 $600 \mathrm{~K} て ゙$ 収縮が開始し， $\mathrm{Al}$ を添加しなかっ た $\mathrm{Fe}_{52} \mathrm{Cr}_{48}$ 粉末より $120 \mathrm{~K}$ 低い温度であった. $0.5 \mathrm{mass} \% \mathrm{Al}$ を添 加することにより, Fe-48at\%Cr合金の特性を損なうことなく， 低温での固化成形を実現できた.

$$
4 \text { ま と }
$$

MA合成した $\mathrm{Fe}_{52} \mathrm{Cr}_{48}$ 粉末に Al 粉末を混合し, SPS 成形を行 い, 焼結性におよぼす $\mathrm{Al}$ 添加の効果について検討した。さら に, 得られた $\mathrm{Fe}_{52} \mathrm{Cr}_{48}$ 粉末 $+\mathrm{Al}$ 合金の特性について調べた.そ の結果, 以下の結論が得られた.

(1) MA 合成した $\mathrm{Fe}_{52} \mathrm{Cr}_{48}$ 粉末と $\mathrm{Al}$ 粉末を遊星型ボールミルを 用いて回転数 150 r.p.m. で 36ks 間混合すると, $\mathrm{Al}$ 粉末と MA 粉末は反応せず, $\mathrm{Al}$ を均質分散することができる.

(2) $\mathrm{Al}$ を添加することにより, Fe-48at\%Cr 合金の SPS 成形に おける収縮開始温度が約 100〜150K低温になる. しかし， 2.5 mass\%以上の $\mathrm{Al}$ を添加した場合, 焼結時に FeAl化合物 
が生成し，硬く脆い材料になる。

(3) 0.5mass\%Al を添加して SPS 成形すると, Fe-48at\%Cr 合金 より $120 \mathrm{~K}$ 低い約 $600 \mathrm{~K}$ から収縮が開始する。得られた焼 結体の組織は均一微細で, そのビッカース硬度は 350〜 $370 \mathrm{Hv}$ を示す.

\section{文献}

1) 日本金属学会: "改訂 4 版金属便覧", 丸善, (1982)525.

2) 日本金属学会: "改訂 4版金属便覧", 丸善,(1982)1245.

3）下平三郎: "高強度フェライトステンレス鋼 (2)", 日本金属 学会会報, 16(1977)157-171.

4）細井祐三："ステンレス鋼の精製技術の進歩と材料の耐食 性", 日本金属学会会報, 16(1977)405-413.

5) 例えば福田 正, 形浦安治, 音谷登平：" $\mathrm{Fe}-30 \% \mathrm{Cr}$ 合金の機 械的性質に及ぼす炭化物および窒化物の影響", 日本金属学 会誌, 54(1990)93-100.
6) Binary alloy phase diagram, American Society for Metals, (1986) 822.

7) 五十嵐 廉, 本吉健也："Fe-Cr-Ni 系焼結合金における $\sigma$ 相 粉末の挙動について", 粉体および粉末治金, 20(1974)261267.

8）松井則男, 小林慶三,杉山明, 尾崎公洋: "メカニカルア ロイング法による Fe-Cr合金の合成とその固化成形", 粉体 および粉末冶金, 44(1997)560-564.

9）松井則男, 小林慶三, 杉山明, 尾崎公洋: "MA粉末をパル 又通電焼結した $\mathrm{Fe}_{52} \mathrm{Cr}_{48}$ 合金の特性 ", 粉体および粉末治金， 44(1997)1121-1125.

10) 小林慶三, 坂崎一茂: "Al液体を利用した FeAl 金属間化合 物の成形", 粉体および粉末治金, 42(1995)1247-1251.

11) 小林慶三, 尾崎公洋, 杉山明, 榛原照男: "メカニカルア ロイング合成した $\mathrm{Al}$ 基合金を用いた $\mathrm{FeAl}$ の合成 ", 43 (1996)1203-1207. 